\title{
$\mathrm{C} 2 \mathrm{C} 12$ 골격근 세포에서 육계, 부자, 갈근 물 추출물의 당대사 및 에너지 조절 효과
}

\author{
송미영
}

동국대학교 한의과대학 한방재활의학교실

\section{The Effects of Cinnamomum cassia Blume, Aconitum carmichaeli Debx, and Pueraria lobata Benth on Glucose and Energy Metabolism in C2C12 Myotubes}

\author{
Mi-Young Song \\ Department of Rehabilitation Medicine of Korean Medicine, College of Korean Medicine, Dongguk University
}

Received: November 8, 2015 Revised: November 23, 2015 Accepted: November 23, 2015

Correspondence to: Mi-Young Song Department of Rehabilitation Medicine of Korean Medicine, College of Korean Medicine, Dongguk University, 123 Dongdae-ro, Gyeongju 38066, Korea Tel: $+82-54-770-1256$ Fax: +82-54-770-1200 E-mail: miyoungsong@dongguk.ac.kr Copyright $\odot 2015$ by The Society of Korean Medicine for Obesity Research
Objectives: The prevalence of obesity and metabolic syndrome is increasing worldwide. Regulation of cellular energy metabolis has the potential to be manipulated therapeutically to serve as a target for obesity and insulin resistance. Skeletal muscle is regarded as a target for regulation of energy metabolism and insulin resistance. In this study, the authors investigated the regulatory effect of (Cinnamomum cassia Blume, CCB), Aconitum carmichaeli Debx (ACD), and Benth (Pueraria lobata Benth, PLB) on energy and glucose metabolism in $\mathrm{C} 2 \mathrm{C} 12$ myotubes.

Methods: The water extracts of CCB, ACD, and PLB $(0.5 \mathrm{mg} / \mathrm{ml})$ were treated in differentiated $\mathrm{C} 2 \mathrm{C} 12$ myotubes. The expressions of adenosine monophosphate-activated protein kinase (AMPK) and phosphorylation AMPK were detected with western blotting. Glucose metabolism was investigated with glucose uptake assay and glucose consumption assay, total adenosine triphosphate (ATP) content was also analyzed.

Results: CCB, ACD, and PLB activated the phophorylation of AMPK, they also increased the glucose metabolism and total ATP contents in $\mathrm{C} 2 \mathrm{C} 12$ myotubes.

Conclusions: This study suggests that CCB, ACD, and PLB have the potential to increase energy and glucose metabolism in skeletal muscle.

Key Words: Cinnamomum cassia Blume, Aconitum carmichaeli Debx, Pueraria lobata Benth, Glucose, Energy, C2C12

\section{서 론}

현대 산업과 기술의 발달로 풍족한 식생활이 가능해지고 육체노동보다 정신노동이 더 많아짐에 따라 소비하는 에너 지(energy expenditure)보다 섭취하는 에너지(energy intake) 가 더 많아지고, 굶주림에 저항하기 위해 신체에 에너지 저 장 시스템을 발달시켜 오던 인류는 잉여에너지를 계속 저장 하게 되었다. 이것은 비만이라는 형태로 나타났으며, 전 세 계적으로 비만과 이로 인한 대사증후군의 유병률이 급증하
고 있는 상황이다 ${ }^{1)}$.

에너지 불균형을 조절하는 것이 비만, 대사증후군 및 제2 형 당뇨 치료의 핵심인데, 에너지 불균형은 에너지 섭취를 줄이거나 혹은 에너지 소비를 증가시키는 방법으로 해결할 수 있다. 식욕억제제를 통한 에너지 섭취 제한, 즉 식이제한 이라는 치료방법은 여러 문제점이 있는데, 우선 향정신성 부작용을 나타내는 식욕억제제의 부작용이 그것이다. 또한 인체의 항상성 조절 기전으로 인해 체중을 감량하게 되면 에너지 효율을 증가시키기 위해 기초대사율을 떨어뜨리게 
되어 결국에는 체중 감량이 더디고, 재증량(요요현상)이 쉽 게 오게 되므로 식이제한이라는 한 가지 작용만을 통한 치 료는 장기간 지속 시 그 효과가 둔화될 수밖에 없다. 따라서 이에 대한 대응으로 최근 비만 및 대사증후군 치료에 있어 서 생체 에너지 조절 새로운 치료 타깃이 되고 있다 ${ }^{2)}$.

골격근이 생체에너지 조절 및 인슐린 저항성 조절에 있 어서 주요 기관으로 밝혀지면서 최근 비만 및 제 2 형 당뇨 연구에서 골격근을 치료 타깃으로 한 연구들이 활발하게 이 뤄지고 있다 ${ }^{3)}$. 골격근에서 생체에너지 조절 및 관련 미토콘 드리아 기능 조절과 관련한 인자에는 여러 가지가 있는데, 그 중 adenosine monophosphate-activated protein kinase (AMPK)는 세포 내에서 에너지 상태를 감지하는 효소로서 근육에서 포도당 및 지방산 대사의 중요한 조절인자로 작용 하는 것으로 알려져 있다 ${ }^{4)}$.

한편 육계(Cinnamomum cassia Blume), 부자(Aconitum carmichaeli Debx) 및 갈근(Pueraria lobata Benth)은 한의 학에서 당뇨병 및 비만 치료제로 활용하고 있는 약물인데, 그 중 육계와 부자는 제 2 형 당뇨병 동물모델에서 이들 약물 의 혈당 강하 효과가 각각 밝혀져 있으며 ${ }^{5)}$, 3T3-L1 지방세 포에서 육계의 지방 분화 억제 효과가 밝혀진 바 있다6). 또 한 갈근은 비만 동물 모델에서 당대사 및 지질대사를 향상 시키는 것이 보고된 바 있닥.

이에 본 연구에서는 생체에너지 조절 및 인슐린 저항성 개선을 위한 당 대사의 핵심 기관인 골격근에서 이들 약물 의 에너지 및 당대사 조절 효능을 $\mathrm{C} 2 \mathrm{C} 12$ 골격근 세포 배양 모델을 통해 연구해보고자 하였다.

\section{재료 및 방법}

\section{1. 약재}

(주)광명당제약(Ulsan, Korea)으로부터 표준약재를 구입 하여 동국대학교 한의과대학 본초학교실에서 감별한 후 정 선하여 시료로 사용하였다. 육계, 부자 및 갈근 각 $200 \mathrm{~g}$ 을 정제수 $2 \mathrm{~L}$ 를 가하여 열탕 추출기에서 3시간씩 2회 가열하 여 얻은 추출물을 여과지(Whatman NO. 1; Sigma-Aldrich, St. Louis, MO, USA)로 여과한 후 회전식 감압농축기로 감 압 농축하여 동결 건조하여서 물 추출물을 제조하였다. 수 득률은 육계 $6.7 \%$, 부자 $22.5 \%$ 및 갈근 $32 \%$ 였다.

\section{2. 세포배양}

마우스 유래 C2C12 세포주는 American Type Culture Collection (ATCC) (CRL-1772; Manassas, VA, USA)으 로부터 분양받아 사용하였다. $\mathrm{C} 2 \mathrm{C} 12$ 근육세포는 $60 \mathrm{~mm}$ petridish에 각각 $1 \times 10^{6}$ 의 seeding한 후, fetal bovine serum $(10 \%)$ 및 penicillin streptomycin (1\%)를 함유한 고농 도 포도당 Dulbecco's modified eagle's medium (DMEM) 에서 $100 \%$ confluence될 때까지 배양하였다. 그 후 horse serum (2\%)으로 근육세포의 분화를 유도하였다. 24시간마다 배지를 교환하면서 4일간 분화시킨 후, 약물을 처리하였다.

\section{3. 세포독성평가}

C2C12에 대한 시료의 세포 생존능 평가는 MTT (thiazoly blue tetrazolium bromid)를 이용하여 측정하였다. $\mathrm{C} 2 \mathrm{C} 12$ 세포를 실험 전날 $1 \times 10^{6}$ cells $/ \mathrm{ml}$ 농도로 96-well plate에 seeding하고, 각 약물 추출물을 $0.2,0.5$ 및 $1.0 \mathrm{mg} / \mathrm{ml}$ 를 처리 하여 24시간 동안 배양하였다. 그 후 배양액을 모두 버리고 DMEM에 녹인 $5 \mathrm{mg} / \mathrm{ml}$ MTT (Sigma-Aldrich)를 $100 \mu \mathrm{l}$ 씩 각 well에 처리하여 알루미늄 호일로 차광시킨 후 2시간 동안 같은 조건에서 배양하였다. 배양액을 모두 제거한 후 DMSO $100 \mu$ 를 처리하고 2시간 방치 후 Microplate reader (Molecular Devices, Sunnyvale, CA, USA)를 이용하여 540 $\mathrm{nm}$ 에서 흡광도를 측정하였다.

\section{Western blot}

AMPK, pAMPK의 단백질 발현량을 Western blot을 수 행하여 측정하였다. 골격근 세포를 분화시킨 후, 각 약물 추 출물 및 메트포민을 처리하여 45분간 처리하였다. 세포를 수거하여 5,000 rpm에서 5분간 원심분리한 후 phosphate buffer saline 용액으로 2회 세척하고 lysis 용액 $(50 \mathrm{mM}$ HEPES, pH 7.4, $150 \mathrm{mM} \mathrm{NaCl}, 1 \%$ deoxycholate, $1 \mathrm{mM}$ ethylenediaminetetraacetic acid, $1 \mathrm{mM}$ phenylmethanesulfonyl fluoride, $1 \mu \mathrm{g} / \mathrm{ml}$ aprotinin)을 이용하여 부유시 킨 후 얼음에 30 분간 반응시켰다. $20 \mu \mathrm{g}$ 의 단백질을 $2 \times$ sample buffer $(100 \mathrm{mM}$ Tris-HCl, pH 6.8, $200 \mathrm{mM}$ dithithreitol, $4 \%$ sodium dodecyl sulfate [SDS], $0.2 \%$ bromophenol blue, $20 \%$ glycerol)와 섞어 $100^{\circ} \mathrm{C}$ 에서 3 분 끍 인 다음 8\% 15\% SDS-polyacrylamide gel electropho- 
resis를 이용하여 분리하였다. 전기영동을 통해 분리된 gel 의 단백질을 nitrocellulose membrane으로 $4^{\circ} \mathrm{C}, 30 \mathrm{~V}$ 로 16 시간 동안 transfer시켰다. Membrane은 $10 \%$ skim milk로 실온에서 1 시간 동안 blocking 한 다음, 각 단백질의 항체 와 상온에서 2시간 반응시켰다. 이를 Tris-buffered saline and Tween 20으로 3회 세척한 후 anti-pAMPK, AMPK (cell signaling)로 각각 처치한 후, 상온에서 1시간 반응시 키고 enhanced chemiluminoesence 용액으로 기질반응시 켜 X-ray film에 감광하였다. X-ray film상의 밴드는 이미 지(Image-J) 프로그램을 이용하여 AMPK에 대한 pAMPK 의 발현 비율로 표시하였다.

\section{Glucose uptake assay}

분화된 골격근 세포에 배지를 glucose-free DMEM에 2-[N-(7-160 nitrobenz-2-oxa-1,3-diazol-4-yl)amino]2-deoxy-d-glucose (NBDG) $150 \mu \mathrm{g} / \mathrm{ml}$ 가 포함된 배지로 교환한 후, 약물의 물 추출물, 양성 대조군인 메트포민(2.5 $\mathrm{mM})$ 과 인슐린(100 nM) 및 glucose uptake inhibitor인 apigenin $100 \mu \mathrm{M}$ 을 각각 처리하였다. 4시간 동안 반응시 킨 후, 배지를 제거하고, $200 \mu \mathrm{l}$ of cell-based assay buffer 를 첨가한 후, 세포의 2-NBDG 흡수량을 fluorescence microscopy (Leica Biosystems, Wetzlar, Germany)를 이 용하여 측정하였다.

\section{Glucose consumption assay}

C2C12 세포를 24-well plates에서 분화시킨 후, phenol red free DMEM에 $11.1 \mathrm{mmol} / \mathrm{L}$ glucose 및 $0.2 \%$ bovine serum albumin가 첨가된 배지로 교환하였다. 약물의 물 추 출물 또는 양성 대조군인 메트포민 $(2.5 \mathrm{mM})$ 과 인슐린(100 $\mathrm{nM}$ )을 각각 24시간 동안 처치한 후, 배지에 남은 glucose 의 양을 glucose oxidase kit (Sigma-Aldrich)을 이용하여 측정하였다.

\section{ATP 측정}

앞서 설명한 세포배양법에 따라 골격근 세포를 분화시킨 후 각 약물 추출물 또는 메트포민을 처리하고 24시간 동안 배양하였다. Adenosine triphosphate (ATP) calorimetric assay kit (BioVision Inc., Milpitas, CA, USA)를 이용하여
제시된 프로토콜에 따라 실험 후 $570 \mathrm{~nm}$ 에서 흡광도를 측 정하였다.

\section{8. 통계분석}

GraphPad Prism (GraphPad Software Inc., San Diego, $\mathrm{CA}, \mathrm{USA})$ 을 이용하여 통계처리하였다. 각 2회의 반복 실 험의 결과를 mean \pm standard errors of mean으로 나타내 고, analysis of variance (Tukey's test)를 사용하여 분석하 였으며, 통계적인 유의성은 P-value가 0.05 이하인 경우에 인정하였다.

\section{결 과}

\section{1. 세포독성}

육계, 부자, 갈근 물 추출물이 각각 농도별로 $\mathrm{C} 2 \mathrm{C} 12$ 의 골격근 세포의 생존율에 미치는 영향을 비교하였다. 24시 간 동안 처리한 결과 모든 농도에서 유의한 변화는 나타나 지 않았다(Fig. 1).

\section{AMPK 활성화 작용}

골격근에서는 $\mathrm{AMPK}$ 는 활성화되면 지방산의 산화와 당 흡수를 촉진하며, 이를 통해 미토콘드리아 내 ATP 생산을 증가시키는 작용을 한다 ${ }^{4}$. 이에 본 연구에서는 대표적인 AMPK activator로서 미토콘드리아 생합성 작용이 알려진

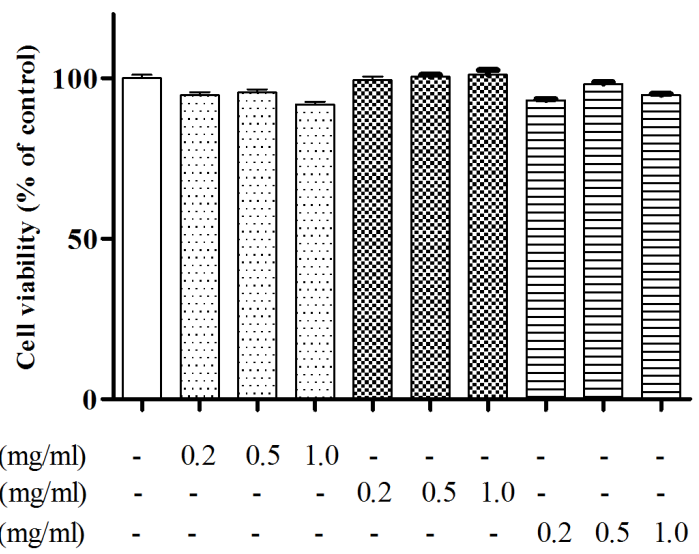

Fig. 1. Effect of Cinnamomum cassia Blume (CCB), Aconitum carmichaeliDebx (ACD), and Pueraria lobata Benth (PLB) on cell viability in $\mathrm{C} 2 \mathrm{C} 12$ myotubes. Cells were incubated for 24 hours. Results are represented as means \pm standard errors of means. 
metformin ${ }^{8}$ 을 양성 대조군으로 설정하여 AMPK, pAMPK 의 단백질 발현량을 측정하였다. 그 결과 육계, 부자, 갈근 모두 $\mathrm{AMPK}$ 의 인산화를 활성화시키는 것으로 나타났으며, 부자, 갈근의 효능이 육계에 비해서 두드러지게 나타났다(Fig. 2).

\section{Glucose uptake 조절 작용}

약물의 당 대사 조절 효능을 형광현미경을 이용하여 2-

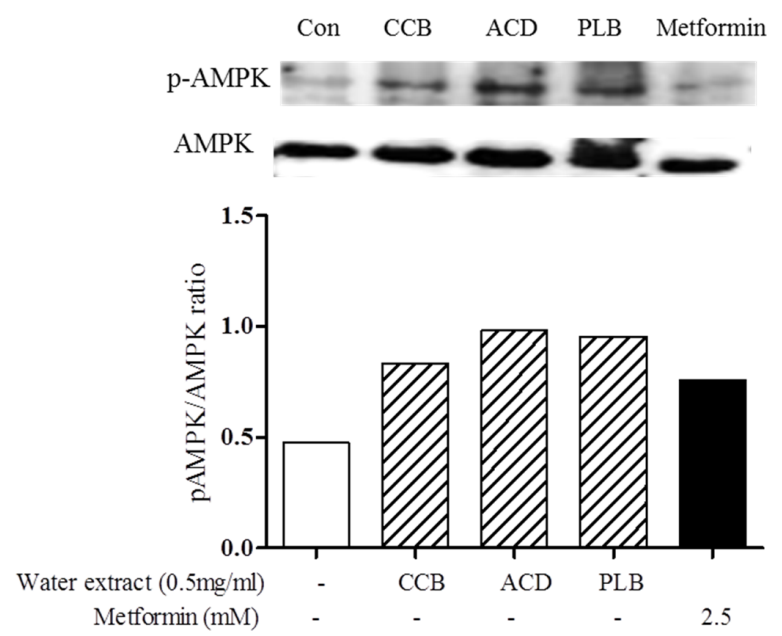

Fig. 2. Effect of Cinnamomum cassia Blume (CCB), Aconitum carmichaeli Debx (ACD), and Pueraria lobata Benth (PLB) on phosphorylation of adenosine monophosphate-activated protein kinase (AMPK) in $\mathrm{C} 2 \mathrm{C} 12$ myotubes. Differentiated cells were treated with CCB, ACD, PLB extract $(0.5 \mathrm{mg} / \mathrm{ml})$ or metformin $(2.5 \mathrm{mM})$ for 45 minutes and then the PAMPK and AMPK protein levels were assessed by Western blotting. Con: control.
NBDG 발현량 측정을 통해 glucose uptake ${ }^{9)}$ 조절력을 분 석하였다. 대조군에 비해 육계, 부자 및 갈근 처치군 모두 glucose uptake가 증가하였으며, 대조 약물인 메트포민, 인 슐린과 유사하게 증가함을 알 수 있었다(Fig. 3).

\section{Glucose consumption 조절 작용}

또한 당 대사 조절과 관련하여 약물 처치 후 배지에 존재 하는 glucose 양을 측정하는 방법을 통해 세포의 glucose 이 용률을 분석하는 추가 실험을 실시하였다. 대조군의 배지 내 glucose 잔여량을 대조군과 비교하였을 때, 실험 약물 모 두 glucose 잔여량이 감소하였으며, 이를 통해 세포 내로 glucose uptake가 더 많이 이뤄졌음을 간접적으로 평가할 수 있었다(Fig. 4).

\section{ATP 조절 작용}

AMPK 등 생체 에너지 조절과 관련된 효소가 증가되면 당과 지방산 대사가 증가되고 최종적으로 ATP 생산이 증가 하게 된다. 앞선 연구에서 약물의 AMPK와 당 대사 조절 효능을 확인하였고, 이로 인한 최종적인 ATP 생산량의 증 가여부를 분석하였다. 육계, 부자, 갈근 모두 대조군에 비해 서 통계적으로 유의하게 ATP 총량을 증가시키는 것으로 나 타났다(Fig. 5).
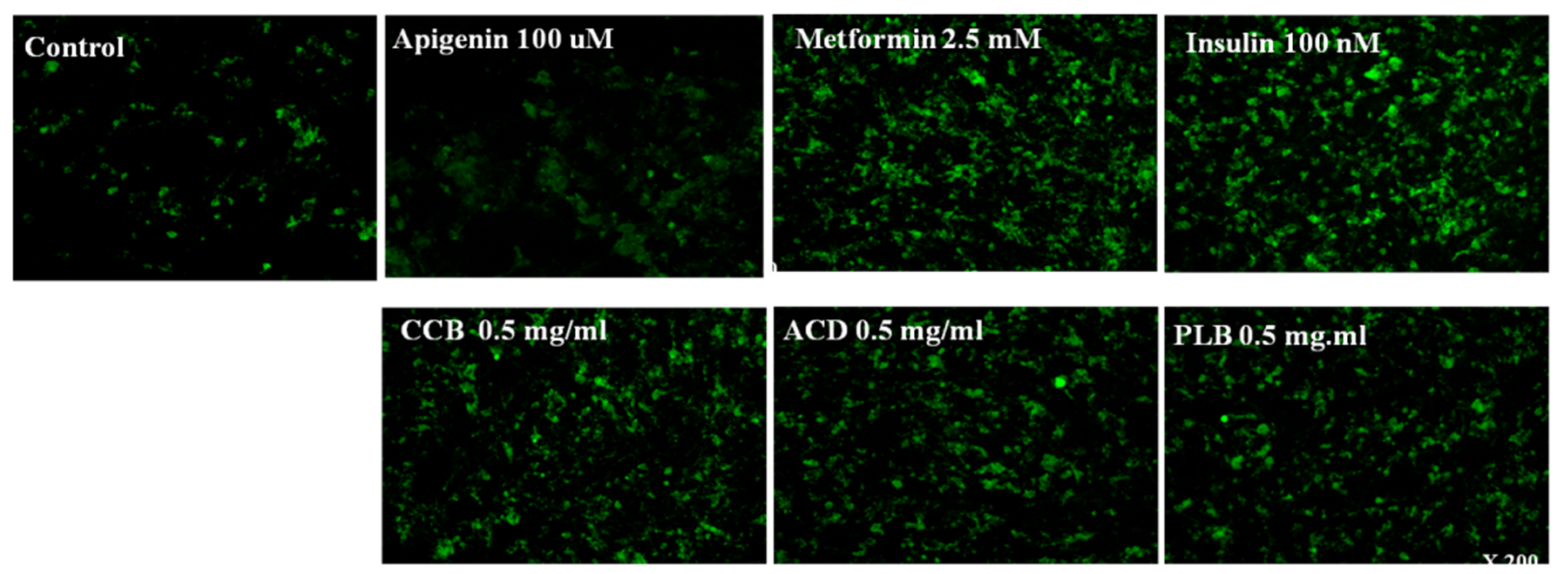

Fig. 3. Effect of Cinnamomum cassia Blume (CCB), Aconitum carmichaeli Debx (ACD), and Pueraria lobata Benth (PLB) on glucose uptake in C2C12 myotubes. Differentiated cells were treated with CCB, ACD, PLB extract $(0.5 \mathrm{mg} / \mathrm{ml})$, metformin $(2.5 \mathrm{mM})$, insulin (100 nM) or apigenin (apigenin is known to inhibit 2-NBDG uptake) $(100 \mu \mathrm{M})$ for 4 hours. Glucose uptakes were observed by the amount of 2-NBDG taken up by cells in fluorescence microscopy $(\times 200)$. 


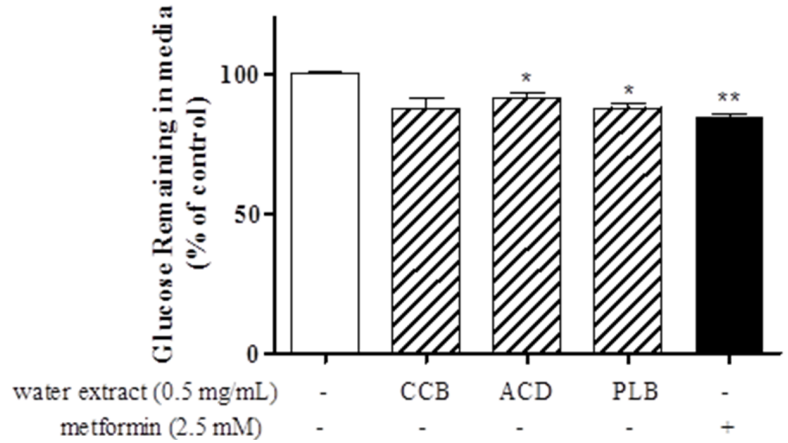

Fig. 4. Effect of Cinnamomum cassia Blume (CCB), Aconitum carmichaeli Debx (ACD), and Pueraria lobata Benth (PLB) on glucose consumption in $\mathrm{C} 2 \mathrm{C} 12$ myotubes. Differentiated cells were treated with CCB, ACD, PLB extract $(0.5 \mathrm{mg} / \mathrm{ml})$ or metformin $(2.5 \mathrm{mM})$ or for 24 hours and then glucose contents in media were determined using glucose oxidase kits. Values in histogram are the means \pm standard errors of means of three independent experiments. ${ }^{*} \mathrm{P}<0.05$, ${ }^{\star \star} \mathrm{P}$ $<0.01$.

\section{고 찰}

에너지 항상성의 불균형은 근육, 간, 지방 세포의 기능 이 상을 초래하고, 그로 인해 비만, 제2형 당뇨 등의 대사성 질 환이 발생된다 ${ }^{9)}$. 에너지 조절과 관련된 효소로 세포 내의 에 너지 항상성 유지에 센서 역할을 하는 AMPK가 대표적인데, 대사성 스트레스나 운동에 의해 세포 내의 에너지가 감소하 는 경우, 즉 ATP가 고갈되어 AMP/ATP 비율이 증가하는 경 우에서 활성화되는 것으로 알려져 있다. 골격근에서는 AMPK 가 활성화되면 지방산의 산화와 당 흡수를 촉진하며, 이를 통 해 미토콘드리아 내 ATP 생산을 증가시키는 역할을 한다 ${ }^{10)}$. $\mathrm{AMPK}$ 가 에너지 불균형과 관련된 대사성 질환 발생에 있어 중요한 역할을 하는 것으로 밝혀져 있으며, $\mathrm{AMPK}$ 를 대사성 질환의 약물 타겟으로 한 많은 연구들이 진행되고 있다 ${ }^{11}$. 본 연구에서는 골격근 세포내 에너지 조절과 관련하여 약물의 $\mathrm{AMPK}$ 의 활성화 작용 효능을 측정하였다. AMPK는 threonine (Thr-172)의 인산화(phosphorylation)를 통해 활성화 되므로 ${ }^{10)}$, AMPK에 대한 $\mathrm{pAMPK}$ 의 단백질 발현량 비교를 통해 그 활성도를 측정하였다. 실험 약물인 갈근, 부자, 육계 모두 pAMPK의 단백질 발현량을 증가시키는 것을 확인할 수 있었다.

또한 비만 및 제2형 당뇨 개선을 위해서는 당 유입을 증가 시켜 ATP 생산을 위한 이화 작용을 촉진시키는 것이 중요하 다. 골격근은 고인슐린 포도당 클램프(euglycemic hyper-

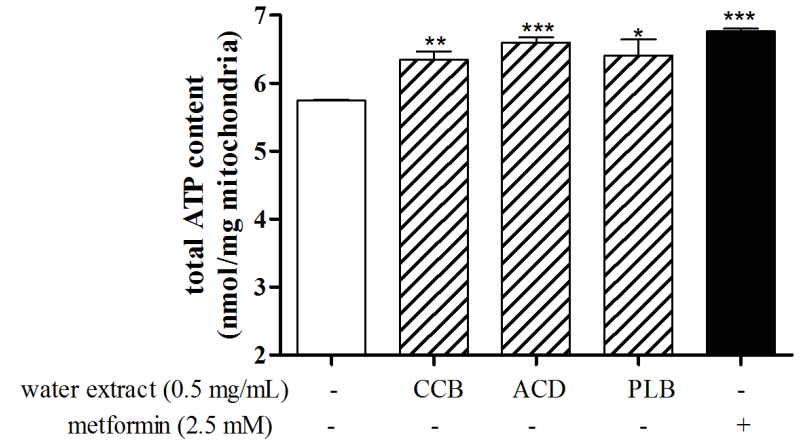

Fig. 5. Effect of Cinnamomum cassia Blume (CCB), Aconitum carmichaeli Debx (ACD), and Pueraria lobata Benth (PLB) on adenosine triphosphate (ATP) content in $\mathrm{C} 2 \mathrm{C} 12$ myotubes. Differentiated cells were treated with CCB, ACD, PLB extract $(0.5 \mathrm{mg} / \mathrm{ml})$ or metformin (2.5 mM) for 24 hours. The total ATP content was measured using ATP calorimetric assay kit. Values in histogram are the means \pm standard errors of means of three independent experiments. ${ }^{*} \mathrm{P}<$ $0.05,{ }^{* *} \mathrm{P}<0.01$, and ${ }^{* * *} \mathrm{P}<0.001$ versus non-treated differentiated cells.

insulinemic clamp)와 같은 고인슐린혈증 상태에서 전신 포 도당 이용/저장의 $70 \%$ 80\%를 차지하는 조직이며, 골격근 에서의 포도당 이용의 감소가 인슐린저항성의 일차적 원인 이 될 것으로 생각하고 있다 ${ }^{12)}$. 본 연구에서는 약물의 골격근 내 당 대사 조절 효능을 2-NBDG를 이용한 glucose uptake 분석 및 배지에 남은 glucose 양을 측정하여 세포의 glucose 이용률을 분석하는 두 가지 방법을 통해 평가하였다. 두 가 지 실험 모두에서 육계, 부자, 갈근이 양성 대조군인 메트포 민 및 인슐린과 유사하게 당 대사를 증가시키는 것으로 나타 났다.

골격근 세포는 미토콘드리아 양이 풍부하여 ATP 생산에 있어서도 중요한 역할을 하는 조직이다. ATP의 원료는 포 도당과 지방산인데, 골격근 내 미토콘드리아 기능 이상으로 포도당과 지방산의 대사가 저하되면서 인슐린 저항성이 발 생하고, 또한 미토콘드리아의 에너지 발생이 감소하는 것으 로 알려져 있다 ${ }^{13,14)}$. AMPK 등 생체 에너지 조절과 관련된 효소가 증가되면, 당과 지방산 대사가 증가되고, 최종적으 로 ATP 생산이 증가하게 되는데 ${ }^{15)}$, 약물의 AMPK 활성화 및 당 대사 증가 효과와 관련성 있게 육계, 부자, 갈근 모두 ATP 생산을 증가시키는 것으로 나타났다.

한편 골격근에서의 에너지 대사 및 인슐린 저항성 조절 에 있어 본 연구에서 분석한 당 대사뿐만 아니라 지방산 산 화도 중요하다. 또한 이와 관련하여 $\mathrm{AMPK}$ 뿐만 아니라, 
PGC1a, SIRT1 등의 인자도 동시에 작용되므로 본 연구 결 과를 바탕으로 이상의 실험을 보완한 후속 심화 연구가 이 뤄져야 하겠다.

\section{결 론}

육계, 부자 및 갈근 물 추출물이 각각 $\mathrm{C} 2 \mathrm{C} 12$ 골격근 세 포에서 AMPK를 활성화시키고, 당 대사를 조절하며, ATP 생산을 늘리는 것으로 나타났다. 이를 통해 이들 약물의 비 만, 인슐린 저항성 및 제2형 당뇨병 치료를 위한 한약 제제 후보 약물로서의 가능성을 확인할 수 있었다.

\section{감사의 글}

본 연구는 보건복지부의 재원으로 한국보건산업진흥원 의 보건의료기술연구개발사업 지원에 의하여 이루어진 것 임(과제고유번호: HI15C0127).

\section{References}

1. Haslam DW, James WP. Obesity. Lancet. 2005 ; 366(9442) : 1197-209.

2. Tseng YH, Cypess AM, Kahn CR. Cellular bioenergetics as a target for obesity therapy. Nat Rev Drug Discov. 2010 ; 9(6) : 465-82.

3. Kelley DE, He J, Menshikova EV, Ritov VB. Dysfunction of mitochondria in human skeletal muscle in type 2 diabetes. Diabetes. 2002 ; 51(10) : 2944-50.

4. Hardie DG, Sakamoto K. AMPK: a key sensor of fuel and energy status in skeletal muscle. Physiology. 2006 ; 21 : 48-60.

5. Jung HS, Song BY, Lee CH, Yook TH. Effects of Cinnamomum cassia and Aconitum carmichaeli's Pharmacopuncture and oral administration on blood sugar in type $\Pi$ diabetic mice. J Korean Acupunct Moxib Soc. 2010 ; 27(5) : 1-12.

6. Han Y, Jung HW, Bae HS, Kang JS, Park YK. The extract of Cinnamomum cassia twigs inhibits adipocyte differentiation via activation of the insulin signaling pathway in 3T3-L1 preadipocytes. Pharm Biol. 2013 ; 51(8) : 961-7.

7. Prasain JK, Peng N, Rajbhandari R, Wyss JM. The Chinese Pueraria root extract (Pueraria lobata) ameliorates impaired glucose and lipid metabolism in obese mice. Phytomedicine. $2012 ; 20(1): 17-23$.

8. Suwa M, Egashira T, Nakano H, Sasaki H, Kumagai S. Metformin increases the PGC- $1 \alpha$ protein and oxidative enzyme activities possibly via AMPK phosphorylation in skeletal muscle in vivo. J Appl Physiol. 2006 ; 101(6) : 1685-92.

9. Zou C, Wang Y, Shen Z. 2-NBDG as a fluorescent indicator for direct glucose uptake measurement. J Biochem Biophys Method. 2005 ; 64(3) : 207-15.

10. Hardie DG. AMP-activated/SNF1 protein kinases: conserved guardians of cellular energy. Nat Rev Mol Cell Biol. 2007 ; 8(10) : 774-85.

11. Ha JH, Lee SH. Role of AMPK in the regulation of cellular energy metabolism. Endocrinol Metab. 2010 ; 25(1) : 9-17.

12. Cho EH, Ko EH, Kim MS, Park JY, Lee KU. Mitochondrial Dysfunction And Insulin Resistance. J Korean Diabetes. 2006 ; 30(6) : 409-15.

13. Petersen KF, Befroy D, Dufour S, Dziura J, Ariyan C, Rothman DL, et al. Mitochondrial dysfunction in the elderly: possible role in insulin resistance. Science. 2003 ; 300(5622) : 1140-2.

14. Kim JA, Wei Y, Sowers JR. Role of mitochondrial dysfunction in insulin resistance. Circulation Res. 2008 ; 102 : 401-14.

15. Hardie D. AMPK: a key regulator of energy balance in the single cell and the whole organism. I J Obes. 2008 ; 32 : S7-S12. 